\title{
Potential of primary kidney cells for somatic cell nuclear transfer mediated transgenesis in pig
}

Anne Richter ${ }^{1}$, Mayuko Kurome ${ }^{1,2}$, Barbara Kessler ${ }^{1}$, Valeri Zakhartchenko ${ }^{1}$, Nikolai Klymiuk', Hiroshi Nagashima², Eckhard Wolf ${ }^{1,2}$ and Annegret Wuensch ${ }^{1 *}$

\begin{abstract}
Background: Somatic cell nuclear transfer (SCNT) is currently the most efficient and precise method to generate genetically tailored pig models for biomedical research. However, the efficiency of this approach is crucially dependent on the source of nuclear donor cells. In this study, we evaluate the potential of primary porcine kidney cells (PKCs) as cell source for SCNT, including their proliferation capacity, transfection efficiency, and capacity to support full term development of SCNT embryos after additive gene transfer or homologous recombination.

Results: PKCs could be maintained in culture with stable karyotype for up to 71 passages, whereas porcine fetal fibroblasts (PFFs) and porcine ear fibroblasts (PEFs) could be hardly passaged more than 20 times. Compared with PFFs and PEFs, PKCs exhibited a higher proliferation rate and resulted in a 2-fold higher blastocyst rate after SCNT and in vitro cultivation. Among the four transfection methods tested with a GFP expression plasmid, best results were obtained with the Nucleofector ${ }^{\mathrm{TM}}$ technology, resulting in transfection efficiencies of $70 \%$ to $89 \%$ with high fluorescence intensity, low cytotoxicity, good cell proliferation, and almost no morphological signs of cell stress. Usage of genetically modified PKCs in SCNT resulted in approximately 150 piglets carrying at least one of 18 different transgenes. Several of those pigs originated from PKCs that underwent homologous recombination and antibiotic selection before SCNT.
\end{abstract}

Conclusion: The high proliferation capacity of PKCs facilitates the introduction of precise and complex genetic modifications in vitro. PKCs are thus a valuable cell source for the generation of porcine biomedical models by SCNT.

Keywords: Pig, Primary kidney cells, Fibroblasts, Nuclear transfer, Genetic engineering

\section{Background}

Over the last years the pig is getting more and more attractive as model organism for biomedical research due to similarities with humans in anatomy, size, physiology, metabolism and pathology (reviewed in [1]). Early sexual maturity and large litter sizes make pigs more suitable for research than other larger animals like cow, sheep or dog (reviewed in [2]). Furthermore, genetically engineered pigs are a promising source of cells, tissues and organs for xenotransplantation (reviewed in [3]).

Genetic modification of pigs can be achieved by a variety of approaches, including pronuclear microinjection of

\footnotetext{
* Correspondence: a.wuensch@gen.vetmed.uni-muenchen.de

${ }^{1}$ Chair for Molecular Animal Breeding and Biotechnology, and Laboratory for Functional Genome Analysis (LAFUGA), Gene Center, Ludwig-MaximiliansUniversität München, Feodor-Lynen-Straße 25, Munich 81377, Germany Full list of author information is available at the end of the article
}

DNA, sperm-mediated gene transfer, retroviral transduction, and somatic cell nuclear transfer (SCNT) using transfected donor cells (reviewed in $[4,5]$ ). Due to the lack of germ line competent pluripotent stem cells in pigs, the latter approach is currently the only route for the generation of gene targeted pigs [6-8]. In addition, SCNT using pools of stable transfected cell clones was an efficient way for the production of transgenic founder pigs with appropriate expression patterns (reviewed in [1,9]) and facilitated the generation of the first pig models with inducible transgene expression [10].

Among the various parameters influencing the outcome of SCNT, such as oocyte quality, nuclear transfer protocol, embryo culture or recipient animal preparation, the type and quality of the nuclear donor cells are of vital importance (reviewed in [11]).

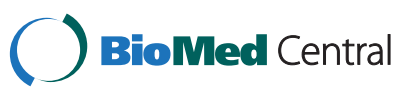

(c) 2012 Richter et al.; licensee BioMed Central Ltd. This is an Open Access article distributed under the terms of the Creative Commons Attribution License (http://creativecommons.org/licenses/by/2.0), which permits unrestricted use, distribution, and reproduction in any medium, provided the original work is properly cited. 
Many primary cell lines established after passaging a primary culture were used for SCNT in pigs, with differences regarding the cell type, source organ, age and gender of the donor animal. Among these cells, mesenchymal stem cells are more or less precisely characterized $[12,13]$. Fibroblast-like cells from fetuses, neonatal, juvenile or adult animals [14-16] or unspecified cells from different organs $[17,18]$ are most widely used. These cells have been tested for their efficiency in SCNT experiments, but further characterization of the specific cell types, their morphology, proliferation, lifespan and stability of karyotype is mostly lacking. The latter parameters are particularly important for advanced genetic modification technologies such as gene targeting, where transfected cells need to undergo homologous recombination, clonal selection and proliferation up to a scale that provides a sufficient number of cells for recombination analysis, cryopreservation and subsequent SCNT experiments. The efficiency of genetic modification of primary cells also depends on the effective introduction of DNA vectors into the cells. Different methods for the transfection of primary mammalian cells have been described, including chemical (calcium phosphate precipitation [19], lipofection [20], nanofection [21]) and physical methods (electroporation [22], nucleofection [23], microinjection [24]) as well as viral transduction [25], but their applicability depends on the cell type into which the DNA has to be introduced.

Here, we characterize for the first time primary kidney cells (PKCs) isolated from kidney samples of juvenile pigs for their proliferation capacity, morphological appearance, stability of karyotype, and uptake of exogenous DNA after application of different transfection methods. Furthermore, we show their potential to support development of SCNT embryos in vitro and of viable genetically modified pigs after additive gene transfer and homologous recombination.

\section{Results}

Morphology and growth potential of PKCs compared to fibroblasts of different origin

Initial morphologic characterization of cells was performed $24 \mathrm{~h}$ after isolation by bright field microscopy. The cultures were usually $70-100 \%$ confluent and displayed a mixture of different cell morphologies. To characterize PKC diversity, the two kidney cell lines $\mathrm{PKCm}$ and PKC2109 were subcloned by generation of single cell clones at passage 3 and their morphology was evaluated 5 to 8 days later (Figure 1 and Additional file 1). The cell clones differed in morphology (fibroblast- or epithelial cell-like), cell size, colony formation (clearly defined or frayed), colony compactness (cell-to-cell distance), growth rate and lifespan.

In parallel, we investigated porcine fetal fibroblasts (PFFs) and ear fibroblasts (PEFs) which also displayed

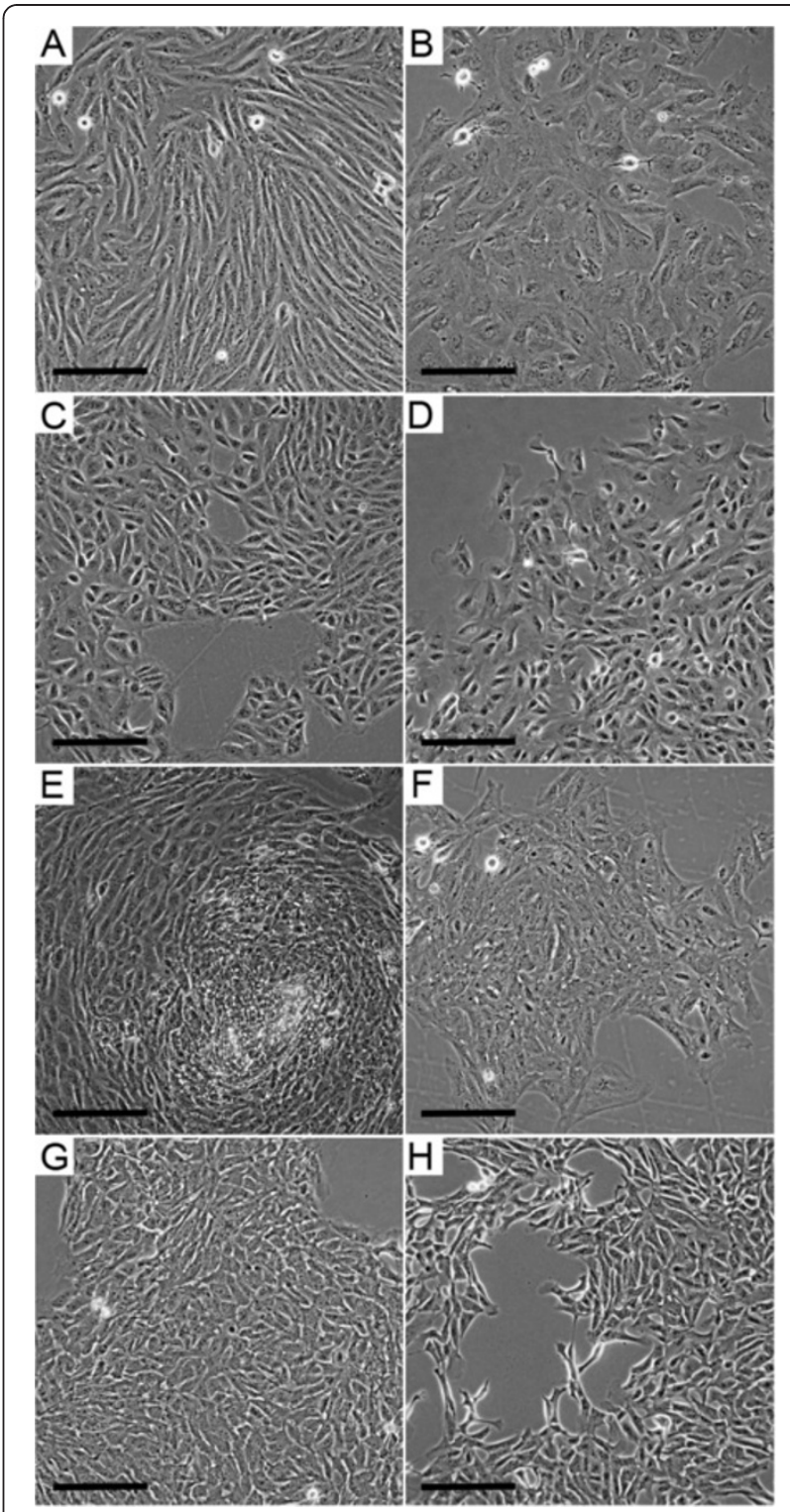

Figure 1 Single cell clone colonies of PKCm at P3. Single cell colonies were generated and analyzed after 7 days. The cells and formed colonies differed morphologically: fibroblast-like cells

[A, B, D-F, H], epithelial- and endothelial-like cells [C, G], cell size (large $[\mathbf{B}]$, smaller $[\mathbf{A}, \mathbf{C}-\mathbf{H}]$ ), colony compactness (cells very close $[\mathbf{A}, \mathbf{E}, \mathbf{G}]$, gaps between cells $[\mathbf{B}, \mathbf{C}, \mathbf{D}, \mathbf{F}, \mathbf{H}]$ ) and colony shape (clearly defined $[\mathbf{A}, \mathbf{C}, \mathbf{E}, \mathbf{G}]$, frayed colonies $[\mathbf{B}, \mathbf{D}, \mathbf{F}, \mathbf{H}]$ ). Scale bar $=100 \mu \mathrm{m}$.

morphological heterogeneity, though to a lesser extent than PKCs. In the primary cell lines PKCm, PKC2109, PFF26 and PEF0110, the heterogeneous appearance diminished with increasing passage numbers and the culture became dominated by cells with spindle shaped fibroblast-like morphology (Figure 2).

In a pilot experiment, PKCs seeded on non-coated cell culture plates did not get properly confluent and rather grew in islands. In contrast, on collagen-coated plates 


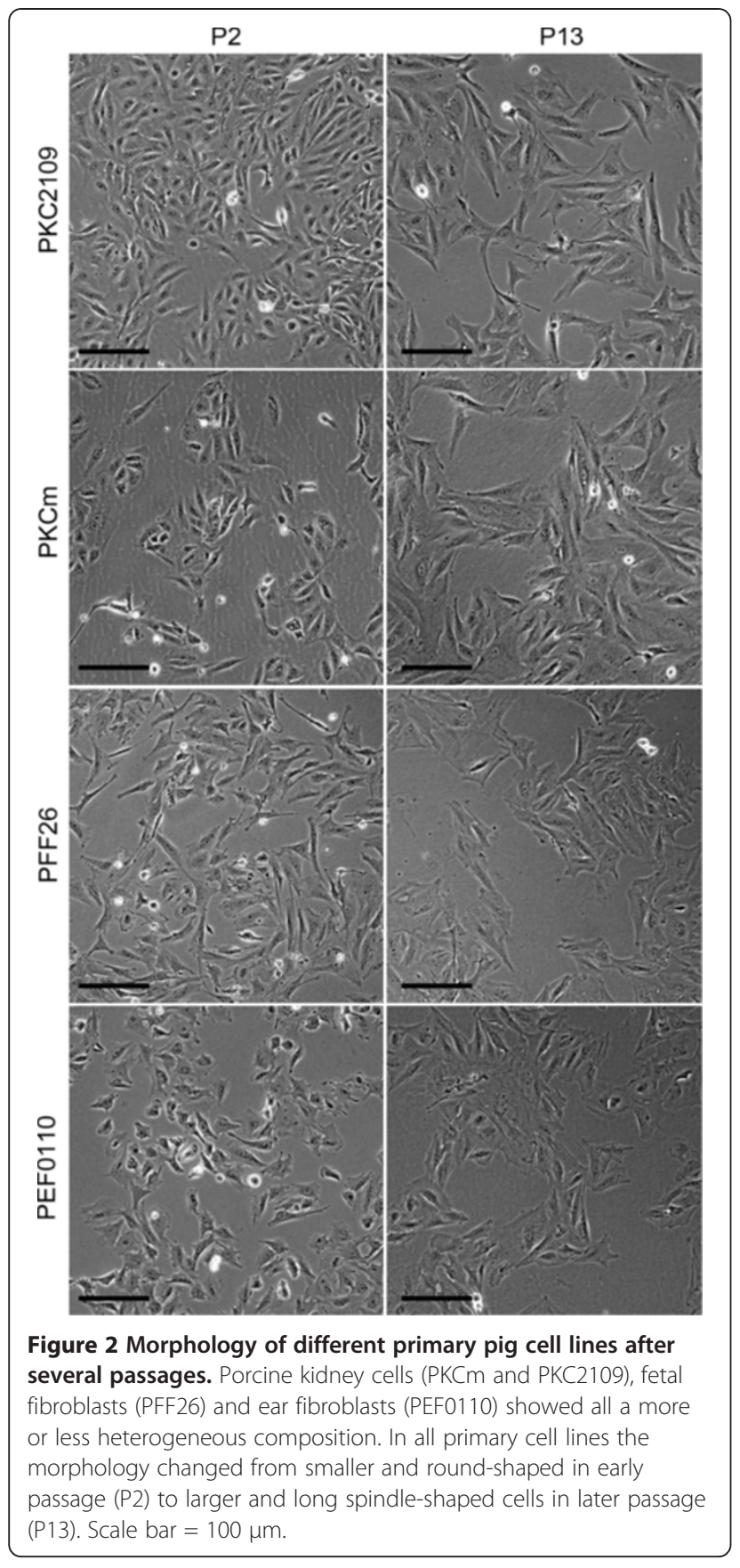

the cells grew evenly spread before reaching confluence (Figure 3A PKCm, B PKC2109). For systematic investigation of the growth behavior of PKCs on different coatings, the proliferation of the primary cell lines $\mathrm{PKCm}$ and PKC2109 was determined $48 \mathrm{~h}$ after seeding of different cell numbers $(2,000,5,000$, or 10,000 cells per well) on gelatin-, collagen- or non-coated 96-well culture plates using an MTT based proliferation assay (Figure $3 \mathrm{~A}$ and $\mathrm{B}$ right diagram). The collagen-coated plates notably promoted proliferation of the cells of both kidney cell lines, as well as PFF and PEF cells (data not shown). Therefore, all further culture experiments were performed in collagen-coated dishes.

Growth behavior and population doubling time of PKCm and PKC2109 was determined and compared to PFF26 and PEF0110 at passage 4-5. Growth curves were generated and population doubling time was calculated in the log phase (Figure 3C). After seeding, PKCm and in particular PKC2109 cells started earlier to proliferate and showed a steeper growth curve than PFF26 and PEF0110 cells. In the exponential growth phase, between 36 and $60 \mathrm{~h}$ after seeding (marked by an $\mathrm{x}$ in Figure 3C), the kidney cell lines exhibited the shortest population doubling time with $15.2 \mathrm{~h}$ (PKC2109) and $16.6 \mathrm{~h}$ (PKCm), followed by PFF26 (23.2 $\mathrm{h})$ and PEF0110 (32.9 h).

In a long-term culture experiment, kidney cells were maintained for a high number of passages - PKC2109 cells at least up to passage 71 and PKCm up to passage 50 - showing only slight signs of senescence, whereas PFF and PEF could hardly be passaged more than 20 times. Karyotype analysis (Figure 3D) revealed 80\% normal chromosome counts in PKCm at passage 3 and $74 \%$ in PKC2109 at passage 71, which was similar to the proportion of normal karyotypes in PFF26 (68\%) and PEF0110 (75\%) determined at passage 13. Due to the fact that it is difficult to prepare appropriate amounts of metaphases from cells with higher passages and cells with more than 12 passages are not used for SCNT in our lab we analyzed PFF26 and PEF0110 at passage 13.

\section{In vitro development of SCNT embryos derived from PKCs, PFFs, and PEFs}

In 3 independent SCNT experiments PKCm, PFF26 and PEF0110 were used as donor cells (Table 1). Fusion rate and the proportion of development to blastocyst were significant higher with $\mathrm{PKCm}$ as donor cells compared to PEF0110. The cell numbers of blastocysts derived from PKCm, PFF26 and PEF0110 donor cells corresponded to $43.5 \pm 4.2,56.1 \pm 9.5$ and $23.5 \pm 7.5$, respectively, and were not significantly different.

\section{Genetic modification of primary PKCs Chemical transfection methods}

Lipofection of PKC2109 resulted in transfection efficiencies of 24 to $52 \%$ using $0.5 \mu \mathrm{g}$ pmaxGFP ${ }^{\mathrm{TM}} \mathrm{DNA}, 0.5$ to $1 \mu \mathrm{l}$ Plus reagent and a lipid to DNA ratio of $2.5: 1$ or 3:1 (Table 2). Thereby, acceptable fluorescence intensities (score: ++ ) were observed, although serious proportions of detached cells indicated a high number of dead cells (rating: 1 to 2 ) and the attached cells were strongly spindle-shaped/partially enlarged and showed vacuoles/lipids (rating: 3 to 5). In the control approach (0 $\mu \mathrm{g}$ DNA, $2.5 \times$ lipid to DNA and $0.5 \mu$ l Plus reagent) cells had a good quality (rating: 1 to 2) without vacuoles and no detached cells (rating: 0; data not shown). 


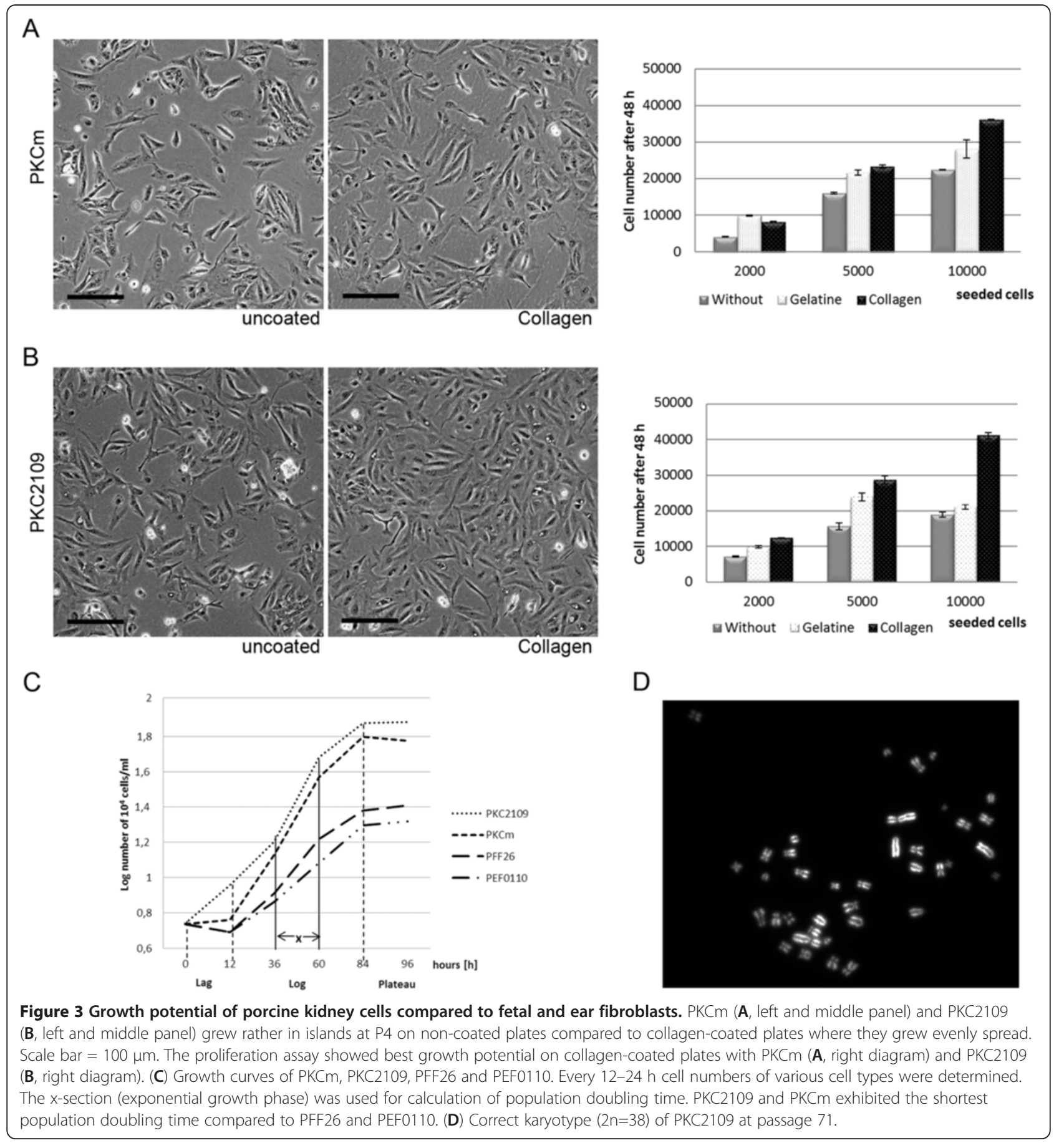

The highest nanofection efficiencies (20 to 25\%) of PKC2109 were obtained using $1 \mu \mathrm{g}$ of DNA and 1.2, 3.2 or $4 \mu \mathrm{l}$ of Nanofectin (Table 3). In these approaches, cell quality (rating: 2) and the proportion of detached cells (rating: 1) were acceptable, but the fluorescence intensity was low when compared to lipofection (score: + to rarely $++)$. The control approaches $(0 \mu \mathrm{g}$ DNA, $3.2 \mu \mathrm{l}$ Nanofectin and $1 \mu \mathrm{g}$ DNA, $0 \mu \mathrm{l}$ Nanofectin, respectively) resulted in excellent to good cell quality (rating: 1) and no cells in suspension (rating: 0 , data not shown).

\section{Physical transfection methods}

To obtain optimal electroporation conditions for PKC2109, different DNA concentrations $(1,5,10,20 \mu \mathrm{g}$ per $0.5 \times 10^{6}$ and $1 \times 10^{6}$ cells, respectively), resuspension buffers (electroporation buffer from Bio-Rad, DMEM, 
Table 1 In vitro development competence of cloned embryos using PKCm, PEF0110 and PFF26

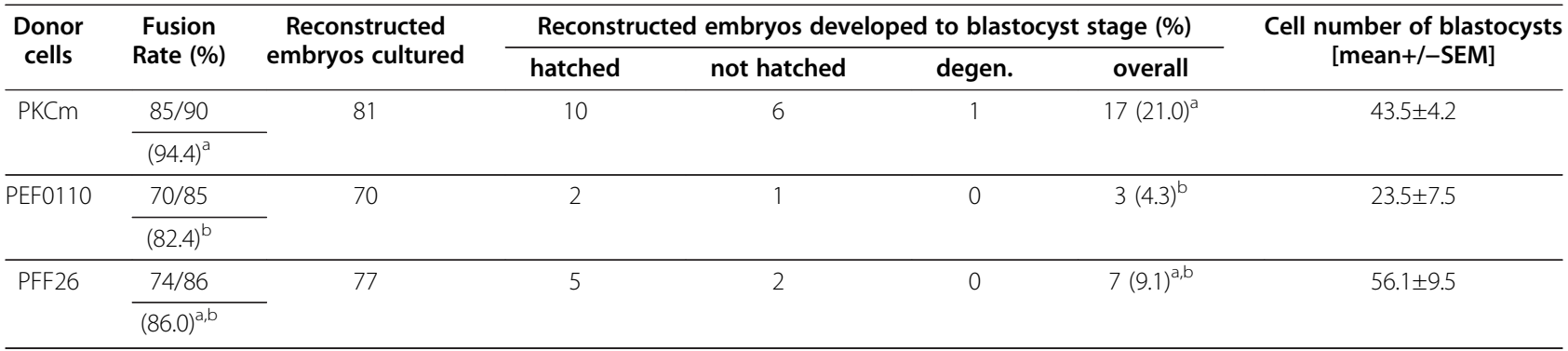

Analysis of blastocysts on day 7. Values with different superscript were significantly different $(\mathrm{P}<0.05)$, SEM = standard deviation. degen.=degenerated.

PBS) and voltages $(100 \mathrm{~V}$ or $230 \mathrm{~V})$ were tested (Table 4). The greatest transfection efficiencies (30 to $54 \%$ ) were determined when using $0.5 \times 10^{6}$ cells (5 or $10 \mu \mathrm{g}$ DNA) and $1 \times 10^{6}$ cells (10 or $20 \mu \mathrm{g}$ DNA) at $230 \mathrm{~V}$. Fluorescence intensity was very good, but a high proportion of cells did not attach after electroporation and indicated a high rate of cell loss during this process (rating: 2). Attached cells showed signs of stress including extreme spindle-shaped morphology and vacuoles (rating: 3 to 5 ). The control experiment $\left(1 \times 10^{6}\right.$ cells, $0 \mu \mathrm{g}$ DNA, electroporation buffer $)$ resulted in stressed cells exhibiting large spindleshaped morphology (rating: 4), but a lower number of cells did not attach (rating: 1; data not shown).

Optimal nucleofection parameters were ascertained in initial experiments by testing various programs offered by the supplier. Program U12 was the most efficient resulting in $63 \%$ transfection efficiency, good fluorescence intensity (score: ++ ) and cells of good quality (rating: 1) using $0.5 \times 10^{6}$ cells of PKC2109, $2 \mu \mathrm{g}$ DNA and 5 different nucleofection programs (Table 5). Therefore, U12 was used for further experiments using different cell numbers and quantity of DNA. Best transfection efficiency (89\%), high fluorescence intensity (score ++ ), low number of cells in suspension (rating: 1) and good quality of cell morphology (rating: 2) was achieved using $0.5 \times 10^{6}$ cells and $20 \mu \mathrm{g}$ DNA. The control experiment $\left(0.5 \times 10^{6}\right.$ cells of PKC2109, $0 \mu \mathrm{g}$ DNA) resulted in best cell quality (rating: 1 ) and a low number of cells in suspension (rating: 1; data not shown). In $\mathrm{PKCm}$, another primary kidney cell line, transfection efficiencies between $49 \%$ and $66 \%$ and high fluorescence intensity (score: ++ to +++ ) were determined using $0.5 \times 10^{6}$ cells and $2 \mu \mathrm{g}$ DNA. Representative pictures of nucleofected PKCs after using $2 \mu \mathrm{g}$ DNA, $0.5 \times 10^{6}$ cells and U12 are shown in Figure 4 .

After testing of 3 different nucleofection programs, U12 was the most efficient program for PFF26, due to

Table 2 Lipofection results PKC2109

\begin{tabular}{|c|c|c|c|c|c|c|}
\hline DNA amount [ $\mu \mathrm{g}]$ & Plus reagent $[\mu l]$ & Ratio lipid to DNA & Quality & Cells in suspension & Fluor. intensity & Transfection efficiency [\%] \\
\hline \multirow[t]{5}{*}{0.25} & 0.25 & $1.0: 1$ & 1 & 0 & + & 0.6 \\
\hline & & $2.0: 1$ & 2 & 0 & + & 0.5 \\
\hline & & $2.5: 1$ & 2 & 0 & + & 3.1 \\
\hline & & $3.0: 1$ & 2 & 0 & + & 3.8 \\
\hline & & $4.0: 1$ & 4 & 0 & ++ & 26 \\
\hline \multirow[t]{4}{*}{0.5} & 0.5 & $1.0: 1$ & 2 & 0 & + & 2.6 \\
\hline & & $2.0: 1$ & 4 & 1 & + & 26 \\
\hline & & $2.5: 1$ & 3 & 1 & ++ & 50 \\
\hline & & $3.0: 1$ & 5 & 2 & ++ & 52 \\
\hline \multirow[t]{2}{*}{0.5} & 1.0 & $2.5: 1$ & 4 & 1 & ++ & 24 \\
\hline & & $3.0: 1$ & 4 & 2 & ++ & 45 \\
\hline \multirow[t]{4}{*}{0.75} & 0.75 & $1.0: 1$ & 4 & 0 & ++ & 28 \\
\hline & & $2.0: 1$ & 5 & 1 & ++ & 37 \\
\hline & & $2.5: 1$ & 5 & 1 & ++ & 28 \\
\hline & & 3.0:1 & 5 & 1 & ++ & 21 \\
\hline
\end{tabular}

Scale for the assessment of cell quality: 1- excellent to good; 2- no vacuoles and lipids detectable, cells are bit stretched; 3- partially vacuoles and lipids, stretched cells; 4- many vacuoles and lipids, stressed cells, partially enlarged cells; 5 - a lot of large vacuoles and lipids, altered morphology and enlarged cells; Scale for the assessment of cells in suspension: $\mathbf{0}$ - none; $\mathbf{1}$ - low number of cells; $\mathbf{2}$ - a lot of cells; Fluor. = Fluorescence. 
Table 3 Nanofection results PKC2109

\begin{tabular}{|c|c|c|c|c|c|}
\hline DNA amount $[\mu \mathrm{g}]$ & Nanofectin $[\mu l]$ & Quality & Cells in suspension & Fluor. intensity & Transfection efficiency [\%] \\
\hline \multirow[t]{4}{*}{0.5} & 1.2 & 1 & 0 & + & 10 \\
\hline & 2.0 & 1 & 0 & + & 16 \\
\hline & 3.2 & 1 & 1 & + & 16 \\
\hline & 4.0 & 1 & 1 & + & 15 \\
\hline \multirow[t]{4}{*}{1.0} & 1.2 & 2 & 1 & + & 25 \\
\hline & 2.0 & 2 & 1 & + & 17 \\
\hline & 3.2 & 2 & 1 & ++ & 21 \\
\hline & 4.0 & 3 & 1 & + & 20 \\
\hline \multirow[t]{2}{*}{1.5} & 2.0 & 3 & 1 & + & 7 \\
\hline & 3.2 & 3 & 1 & ++ & 11 \\
\hline
\end{tabular}

Scale for the assessment of cell quality: 1- excellent to good; 2- no vacuoles and lipids detectable, cells are bit stretched; $\mathbf{3}$ - partially vacuoles and lipids, stretched cells; Scale for the assessment of cells in suspension: $\mathbf{0}$ - none; $\mathbf{1}$ - low number of cells; $\mathbf{2}$ - a lot of cells; Fluor. = Fluorescence.

transfection efficiency of 53\%, excellent cell quality (rating: 1) and low number of cells in suspension (rating: 1 ).

Transfection of the primary cell line PEF0110 using 3 different nucleofection programs resulted in poor transfection efficiencies (11 to 34\%) and low fluorescence intensity (score: + ).

Among the different transfection methods used for transient transfection of PKC2109, nucleofection is the most suitable, since it is highly efficient and results in viable cells of good quality.

\section{Generation of transgenic animals using PKCs as donor cells \\ Additive gene transfer and re-cloning}

For the generation of transgenic animals by additive gene transfer (Figure 5A), resulting in random integration of a gene construct into the genome, wild-type cells were transfected with a gene construct including the gene of interest and a resistance gene for the generation of stable transfected cell clones after antibiotic selection. Since a mixed population of transfected and selected cell clones was used for SCNT, the generated animals had to be examined for transgenesis and expression level in the organs and tissues of interest. The best expressing animals were used for breeding, for re-cloning or for a second transfection with further gene constructs to generate multi-transgenic animals.

In summary 7 different primary porcine kidney cell populations, including $\mathrm{PKCm}$ and $\mathrm{PKC} 2109$, isolated from neonatal to 13-month-old wild-type or transgenic pigs served as donor cells for SCNT after one or two nucleofection rounds with 11 different gene constructs [10]. In re-cloning experiments, 5 different PKC lines isolated from neonatal to 13-month-old cloned transgenic pigs without any further genetic modification served as donor cells for SCNT [10]. Overall the litter rate and size were satisfying, where 38 embryo transfers after cloning of transfected cells resulted in 22 litters (58\%) with 83 animals and 35 embryo transfers after re-cloning gave rise to 16 litters (46\%) with 48 piglets. Hence, different primary kidney cells, including PKCm and PKC2109, were capable of producing genetically modified pigs by additive gene transfer. The efficiency in transgenic pig delivery did not show significant differences between PKC2109, $\mathrm{PKCm}$ and the fibroblasts examined ( $\mathrm{M}$. Kurome et al., unpublished data).

Table 4 Electroporation results PKC2109

\begin{tabular}{|c|c|c|c|c|c|}
\hline Cell number & DNA amount $[\mu \mathrm{g}]$ & Quality & Cells in suspension & Fluor. intensity & Transfection efficiency [\%] \\
\hline \multirow[t]{3}{*}{$0.5 \times 10^{6}$} & 1 & 3 & 1 & + & 28 \\
\hline & 5 & 3 & 2 & + & 46 \\
\hline & 10 & 3 & 2 & ++ & 47 \\
\hline \multirow[t]{4}{*}{$1.0 \times 10^{6}$} & 1 & 4 & 2 & + & 24 \\
\hline & 5 & 4 & 2 & + & 22 \\
\hline & 10 & 4 & 2 & ++ & 30 \\
\hline & 20 & 5 & 2 & +++ & 54 \\
\hline
\end{tabular}

Scale for the assessment of cell quality: 1- excellent to good; $\mathbf{2}$ - cells are bit stretched/strongly fibroblast-like; 3- stretched cells with vacuoles; 4- very spindleshaped morphology 5- extreme spindle-shaped cells with vacuoles; Scale for the assessment of cells in suspension: $\mathbf{0}$ - none; 1- low number of cells; 2- a lot of cells; Fluor. = Fluorescence. Endotoxin-free purified DNA was used; Voltage: 230V. 
Table 5 Nucleofection results PKC2109, PKCm, PFF26 and PEF0110

\begin{tabular}{|c|c|c|c|c|c|c|}
\hline Cell Number & DNA amount $[\mu \mathrm{g}]$ & Program & Quality & Cells in suspension & Fluor. intensity & Transfection efficiency [\%] \\
\hline \multicolumn{7}{|l|}{ PKC2109 } \\
\hline \multirow[t]{5}{*}{$0.5 \times 10^{6}$} & 2 & A24 & 2 & 1 & + & 28 \\
\hline & 2 & U23 & 2 & 2 & + & 60 \\
\hline & 2 & U12 & 1 & 1 & ++ & 63 \\
\hline & 2 & $\mathrm{~T} 16$ & 2 & 1 & + & 54 \\
\hline & 2 & V13 & 1 & 1 & ++ & 59 \\
\hline \multirow[t]{4}{*}{$0.5 \times 10^{6}$} & 1 & U12 & 1 & 1 & + & 36 \\
\hline & 5 & U12 & 1 & 1 & ++ & 70 \\
\hline & 10 & U12 & 1 & 1 & +++ & 77 \\
\hline & 20 & U12 & 2 & 1 & ++ & 89 \\
\hline \multirow[t]{3}{*}{$1.0 \times 10^{6}$} & 5 & U12 & 1 & 1 & ++ & 68 \\
\hline & 10 & U12 & 1 & 1 & +++ & 88 \\
\hline & 20 & U12 & 2 & 2 & +++ & 83 \\
\hline \multicolumn{7}{|l|}{$\mathrm{PKCm}$} \\
\hline \multirow[t]{3}{*}{$0.5 \times 10^{6}$} & 2 & U12 & 1 & 1 & ++ & 49 \\
\hline & 2 & $\mathrm{~T} 16$ & 1 & 1 & ++ & 50 \\
\hline & 2 & V13 & 2 & 1 & +++ & 66 \\
\hline \multicolumn{7}{|l|}{ PFF26 } \\
\hline \multirow[t]{3}{*}{$0.5 \times 10^{6}$} & 2 & U12 & 1 & 1 & + & 53 \\
\hline & 2 & $\mathrm{~T} 16$ & 1 & 1 & + & 50 \\
\hline & 2 & V13 & 2 & 2 & ++ & 77 \\
\hline \multicolumn{7}{|l|}{ PEF0110 } \\
\hline \multirow[t]{3}{*}{$0.5 \times 10^{6}$} & 2 & U12 & 1 & 1 & + & 15 \\
\hline & 2 & T16 & 1 & 1 & + & 11 \\
\hline & 2 & V13 & 2 & 2 & + & 34 \\
\hline
\end{tabular}

Scale for the assessment of cell quality: 1- excellent-good; 2- cells are bit stretched/strongly fibroblast-like; 3 - stretched cells with vacuoles; 4- cells with very spindle-shaped morphology 5- extreme spindle-shaped with vacuoles; Scale for the assessment of cells in suspension: 0- none; 1- low number of cells; 2- a lot of cells; Fluor. $=$ Fluorescence.

\section{Gene targeting}

In contrast to additive gene transfer, where pools of stable transfected cell clones can be used for SCNT, gene targeting requires clonal selection, which means the generation of individual cell clones and their analysis for homologous recombination. Figure $5 \mathrm{~B}$ shows the sequential gene targeting of 2 alleles for the production of a homozygous knockout pig. The PKCm line was used for targeting of 3 different loci [8], using linearized BAC-DNA. After a first round of transfection and selection, correctly targeted cell clones (1 allele) were used for SCNT. In summary, 19 ETs resulted in 7 litters (37\%) with a total of 28 animals (including 1 stillborn) and 2 interrupted pregnancies (day 58 and 61) containing 17 fetuses. PKCs from heterozygous animals were used for targeting of the second allele of the locus. After transfer of embryos to 4 recipients 2 litters (50\%) with 11 offspring (including 2 stillborn) were obtained. Thus, SCNT using targeted PKCm clones resulted in acceptable pregnancy rates and litter sizes.

\section{Discussion}

Various types of primary transgenic or non-transgenic porcine cells were used as nuclear donors for the production of cloned embryos or piglets, but the characterization of the cells is normally restricted to the efficiency of transgenic animal production. Nonetheless, a comprehensive analysis of defined cell lines might facilitate choosing appropriate cell types for advanced transgenic strategies and improve the use of primary cells for the production of large animal models. We used two different primary kidney cell lines and compared them with fetal or ear fibroblasts and observed that subclones of these cells differ in morphology and growth potential. Various groups verified different types of fibroblasts (cortical and inner medullary fibroblasts) and other cell types such as dendritic cells, macrophages and lymphocyte-like cells in kidney cell cultures (reviewed in $[26,27])$. In our hands, the diversity of cell morphologies decreased over several passages in all investigated cell lines, probably due to the culture conditions promoting 

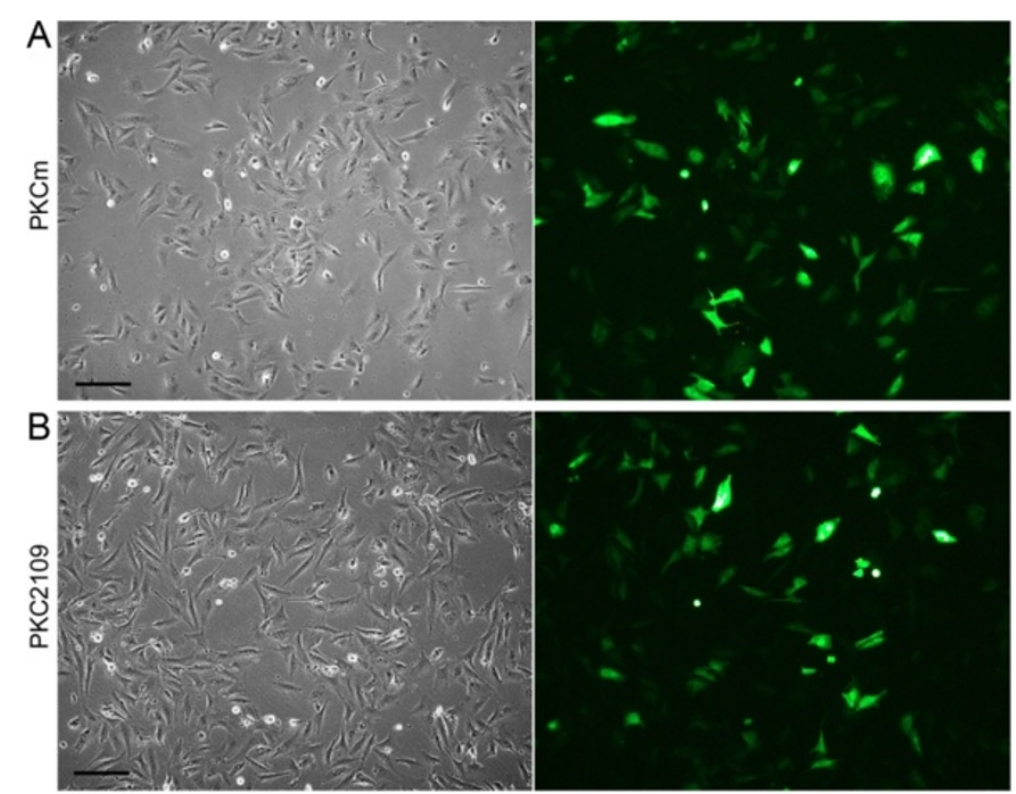

Figure 4 Transiently nucleofected porcine kidney cells. PKCm (A) and PKC2109 (B) $24 \mathrm{~h}$ after nucleofection with a GFP expressing plasmid using $0.5 \times 10^{6}$ cells and $2 \mu \mathrm{g}$ DNA at passage 4 . Scale bar $=100 \mu \mathrm{m}$.

proliferation of few fibroblast-like cell types and a different lifespan of cultured cell types. Regarding the growth potential, PKCs grew faster than fetal or ear fibroblasts, although the kidney cells were isolated from 3-month-old animals, whereas PFF originated from a fetus and the PEF from a neonatal ear. The diversity of cell types in PKCs might influence the growth of cell population in a positive way due to factors which are produced by neighboring cells, e.g. the extracellular matrix produced by renal fibroblasts [26]. However, we showed that all investigated cells, including the kidney cells, grew better on coated compared to non-coated plates. It has already been shown that collagen type I, which is part of the extracellular matrix, is a prevalent substrate for the culture of several cell types, including human skin fibroblasts [28] and PFFs [7].

Various methods have successfully been used to introduce exogenous DNA into porcine fibroblasts. During chemical transfection, we suggest that the vesicles were formed of big DNA-lipid conglomerates and the vacuoles probably originate from cell stress during transfection. Overall, our lipofection results are very heterogeneous due to the numerous parameter combinations (ratio of DNA to lipid, amount of DNA, Plus-reagent and lipofection solution) which had to be tested. The tested chemical transfection methods and in addition the conventional electroporation were not suitable for efficient transfection either due to low transfection efficiencies, formation of vacuoles and lipids or high toxicity.

Nucleofection has been used for transfection of various cells $[23,29]$. We achieved best results by nucleofection of PKCs with $70 \%$ to $89 \%$ transfection efficiency, which is comparable to the efficiency of $90 \%$ in PFFs [30]. In general, after nucleofection of all primary cell lines (PKC, PFF and PEF) we observed low cytotoxicity and only marginal changes of cell morphology. This confirms partly previous studies using the nucleofection technology, showing no effects on cell properties, such as alteration of cell morphology, response to chemicals and pattern of gene expression [31,32].

Using PKCs as donor cells for SCNT, the obtained blastocyst rate of $21 \%$ was higher in comparison to other reports showing a blastocyst rate of 4 to $14.8 \%$ after 6-7 days $[17,18]$ of embryo in vitro culture. The SCNT with PFFs as donor cells resulted in a blastocyst rate of 9.1\%. In other studies the blastocyst rate using PFFs ranged from 11.9 to $31.2 \%[12,16,33,34]$, which is several times higher compared to our blastocyst rate. Nevertheless, it is difficult to compare cloning efficiencies between different laboratories, because a plethora of parameters influences the outcome of SCNT experiments. Even cell cultures from the same fetus may differ in their development capability of embryos after SCNT [35,36]. Moreover, the blastocyst rate is not compulsory meaningful for in vivo developmental competence, it rather gives a rough estimation of the principle applicability of a defined primary cell line as a donor for SCNT.

In the last years, the generation of cloned transgenic pigs using nucleofected fibroblasts from fetal or ear tissue was quite successful in our lab $[9,10,37]$. The usage PKCs for SCNT after transfection and for re-cloning [10] was in our hands satisfying and comparable to PFF, whereas it has to be kept in mind that different gene 
A

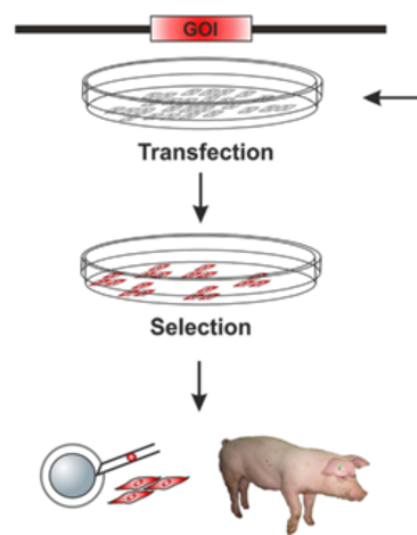

Nuclear transfer - Embryo transfer

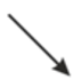

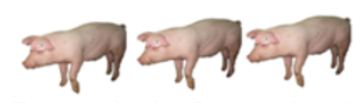

Transgenic pigs for experiments

or breeding

$\uparrow$

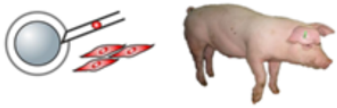

Nuclear transfer - Embryo transfer

$\uparrow$

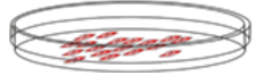

Primary cells for recloning or second transfection

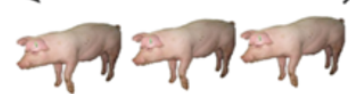

Genotyping - Expression analysis

B

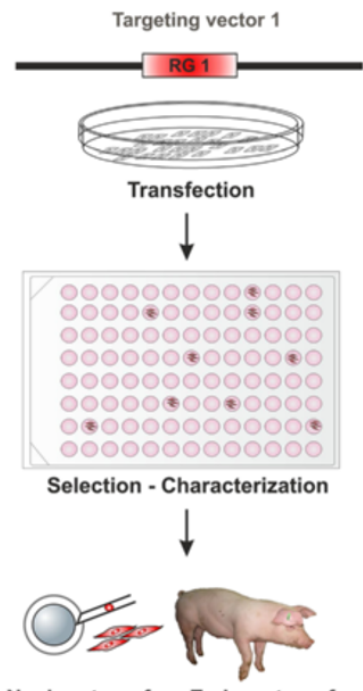

Nuclear transfer - Embryo transfer
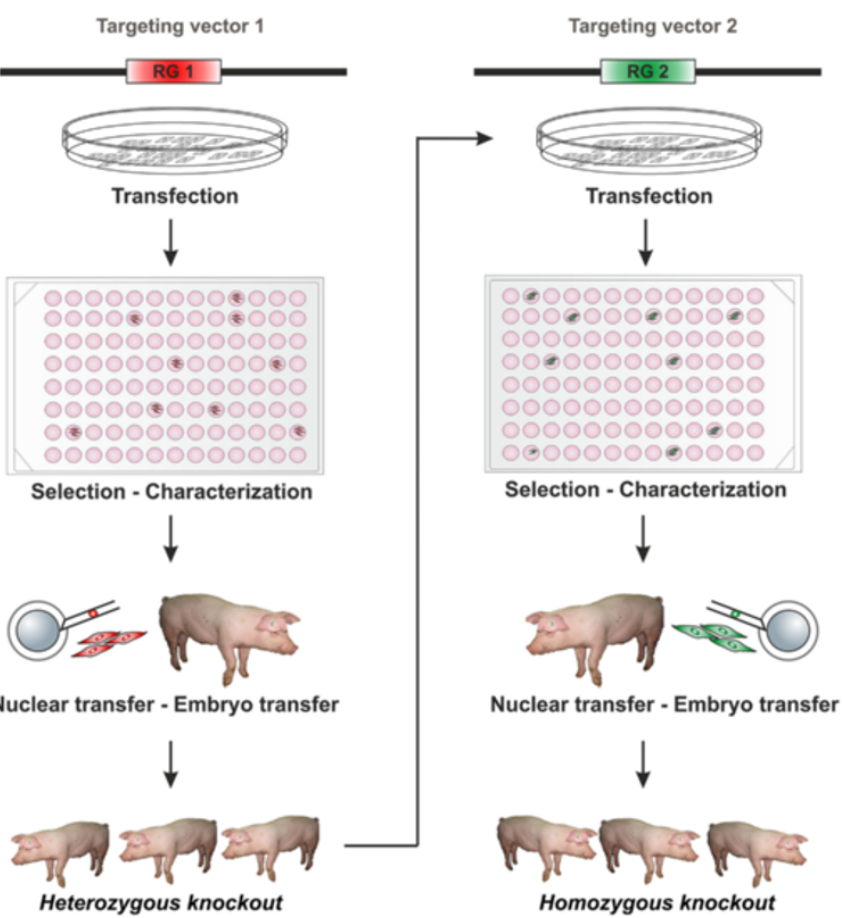

Figure $\mathbf{5}$ Generation of transgenic pigs by additive gene transfer and gene targeting combined with SCNT. (A) Additive gene transfer. Cells are transfected with a vector containing the gene of interest $(\mathrm{GOl})$ and a resistance gene. After antibiotic selection the single cell clones are mixed and transferred to an enucleated oocyte (SCNT) followed by an embryo transfer (ET) to synchronized gilts. After genotyping and gene expressing analysis of the born pigs the best expressing animal is re-cloned or used for a second round of transfection. (B) Gene targeting. In the first targeting round the cells are transfected with a targeting vector containing beside homologous regions of the target locus, a resistance gene (RG1). After selection and characterization of the generated single cell clones, heterozygous knockout cells are used for SCNT followed by the ET. For the targeting of the second allele cells isolated of the heterozygous knockout animals are used for a second round of transfection, using a second targeting vector with another resistance gene (RG2). All following procedures resemble the first round. 
constructs were used. Furthermore, we were able to target successfully 3 different loci in PKCs by homologous recombination [8] and SCNT with several of these correctly targeted cell clones resulted in litter rates of 37 to $50 \%$. Rogers et al. [7] verified that homologous recombination depends on donor cells, because they achieved targeting frequencies between 0.07 to $10.93 \%$ using various primary PFF cultures prepared from different fetuses, but from same uterus at the same time [7]. This underlines the importance of characterization of donor cell cultures provided for genetic modification and SCNT.

Beside the easy isolation procedure and good proliferation capacity of kidney cells it has to be mentioned that for the generation of multi-transgenic pigs and re-cloning kidney cells can be isolated after killing the animals for gene expression analysis anyway or from a biopsy taken from the living animal.

\section{Conclusion}

Our porcine kidney cells are probably a mixture of different cell types showing better proliferation rate, growth capacity, transfection efficiency and blastocyst rate after SCNT compared to PFFs and PEFs. There is no evidence that this mixed population has a negative influence on transfection and further procedures which are necessary for transgenic pig production. Primary porcine kidney cells are highly suitable for additive gene transfer and gene targeting, and subsequent production of genetically modified pigs by SCNT. It has to be kept in mind that each primary cell culture originates from a different animal and preparation, and might show different properties. However, our dataset includes kidney cells from different animals and preparations all showing the same basic characteristics.

\section{Methods}

Animal care

All animal procedures in this study were performed according to the German Animal Welfare Act and to a protocol approved by the Regierung von Oberbayern.

\section{Cell culture}

Porcine fetal fibroblasts (PFFs), porcine ear fibroblasts (PEFs) and porcine kidney cells (PKCs) were principally cultured as mentioned below unless not otherwise noted. Cells were grown on collagen type 1-coated (Serva Electrophoresis, Heidelberg, Germany) cell culture dishes, in medium containing Dulbecco's modified Eagle medium (DMEM; Invitrogen, Darmstadt, Germany) supplemented with $293 \mathrm{mg} / \mathrm{l} \mathrm{L}$-glutamine, 100 units/ml penicillin, $100 \mu \mathrm{g} / \mathrm{ml}$ streptomycin (PAA, Pasching, Austria), $0.1 \mathrm{mM}$ 2-mercaptoethanol (Sigma-Aldrich, Steinheim, Germany), $1 \%$ (v/v) nonessential amino acid and 1\% (v/v) sodium pyruvate (Invitrogen) and different amounts of fetal calf serum (FCS; Invitrogen) depending on the primary cell line (PKC 10\%, PFF and PEF 15\% (v/v)). The cells were cultured at $37^{\circ} \mathrm{C}$ in a humid atmosphere of $5 \%$ $\mathrm{CO}_{2}$ in air. PFF and PEF were harvested using 0.1\% trypsin (Difco ${ }^{\mathrm{TM}}$, Becton Dickinson, Heidelberg, Germany)/ 0.008\% EDTA (Sigma-Aldrich) solution and PKC were harvested with $0.4 \%$ trypsin/ $0.032 \%$ EDTA. The split ratio of the cells was between 1:2 and 1:4 depending on confluence and growth potential of the cells.

\section{Cell isolation}

After slaughter the kidney (for PKCs) or the uterus containing the fetus (for PFFs) were excised surgically. The ear tissue (for PEFs) was obtained from a living animal by cutting a piece from the ear using a pincer. In general, tissue pieces were stored in washing buffer (PBS with 1-2\% (v/v) Pen/Strep and 1-2\% (v/v) Amphotericin $\mathrm{B}(\mathrm{PAA}))$ in the refrigerator or on ice until isolation. The isolation of the primary cell lines PKC2109 from a 3-month-old male pig and PEF0110 form a neonatal female piglet was conducted by the same way. Pieces taken from the cortex and medulla of the kidney $(2 \times 1 \times 1 \mathrm{~cm})$ and from the ear $(0.5 \times 0.5 \mathrm{~cm})$ were washed twice in washing buffer, minced and washed with DMEM by centrifugation $(5-10 \mathrm{~min} ; 180 \times \mathrm{g}$ ) until the supernatant became clear. Subsequently, the pelleted tissue pieces were resuspended in $15 \mathrm{ml}$ Hank's Buffered Salt Solution (HBSS; PAA) with $0.1 \%(\mathrm{w} / \mathrm{v})$ collagenase II (Invitrogen) and incubated at $37^{\circ} \mathrm{C}$ while stirring for 1 to $1.5 \mathrm{~h}$ (kidney) or $2 \mathrm{~h}$ (ear). After incubation, flasks were filled up to $50 \mathrm{ml}$ with DMEM, filtered through a $100-\mu \mathrm{m}$ mesh and washed with DMEM (5-10 $\mathrm{min}, 180 \times \mathrm{g})$ until the supernatant became clear. Depending on pellet size $1 / 6$ to $1 / 24$ of the resuspended PKCs were seeded per $100 \mathrm{~mm}$ plate and all resuspended PEFs onto a $60 \mathrm{~mm}$ plate. The isolation of the primary cell line PKCm from the kidney (cortex and medulla) of a 3-month-old male pig was basically the same with the following modifications. The collagenase digestion was done at $37^{\circ} \mathrm{C}$ with shaking every 15 min, and after digestion the remaining tissue pieces were further treated using $0.25 \%$ trypsin/0.02\% EDTA for 15 $\min$ at $37^{\circ} \mathrm{C}$.

For the isolation of PFF26, the backbone of a 27-day-old male fetus was prepared by removing head, legs and internal organs and washed 3 times in PBS containing $1 \times$ Pen/Strep, minced and washed twice in DMEM. Tissue was resuspended and incubated in EGTA buffer [38] rotating in front of an infrared lamp at $37^{\circ} \mathrm{C}$ for $33 \mathrm{~min}$. Afterwards, tissue pieces were centrifuged, resuspended in DMEM containing $1 \mathrm{mg} / \mathrm{ml}(\mathrm{m} / \mathrm{v})$ collagenase II and $1 \mathrm{mg} / \mathrm{ml}$ hyaluronidase and incubated for $20 \mathrm{~min}$ at $37^{\circ} \mathrm{C}$. After washing by centrifugation, tissue pieces were 
incubated in DMEM with $1 \mathrm{mg} / \mathrm{ml}(\mathrm{m} / \mathrm{v})$ dispase and digested for $40 \mathrm{~min}$ at $37^{\circ} \mathrm{C}$. Afterwards, the cells were washed by centrifugation, resuspended in DMEM, filtered through a tea strainer and washed twice in DMEM. The whole cell pellet was resuspended in culture medium and seeded onto a $100 \mathrm{~mm}$ petri dish.

\section{Chromosome preparation}

The metaphase spreads were prepared according to standard protocols [39]. In brief, the cells were harvested with a confluence of $60-90 \%$, incubated with Colcemide (Invitrogen) $(10 \mu \mathrm{g} / \mathrm{ml})$ for $1 \mathrm{~h}$ at $37^{\circ} \mathrm{C}$, followed by hypotonic treatment $(75 \mathrm{mM} \mathrm{KCl})$ for $15 \mathrm{~min}$ at $37^{\circ} \mathrm{C}$, fixed and washed 3 times with ice-cold fixative (75\% methanol, $25 \%$ glacial acetic acid). Then, cell suspension was dropped onto $45^{\circ} \mathrm{C}$ preheated glass slide, dried and chromosomes were mounted with Vectashield antifade solution containing 4,6'-diamidino-2-phenylindole (DAPI; Vector Laboratories, Burlingame, CA, USA) for counterstaining. Metaphases were analyzed using an inverted epifluorescence microscope (Axiovert 200M; Zeiss, Germany). Chromosomes were counted using the ImageJ software.

\section{Growth curve}

$5.5 \times 10^{4}$ cells of the primary cell lines PKCm, PFF26, PEF0110 were plated onto 12-well plates and cultured under standard conditions. Over a period of 5 days, 3 wells of each culture were trypsinized and counted every $12 \mathrm{~h}$. Population doubling was calculated by the following formula using the time between the 2 measurement points of $36 \mathrm{~h}$ and $60 \mathrm{~h}$ :

$\underline{[\log (\text { counted cell number })-\log (\text { starting cell number })]}$ $\log (2)$

\section{Cell proliferation assay}

Different cell numbers $(2,000,5,000$, or 10,000) of PKC2109 and PKCm were seeded in duplicates onto 96well plates $48 \mathrm{~h}$ before treatment with MTT. To obtain a standard curve with defined cell numbers, seven measuring points in duplicates were applied: 250-50000 cells per well (PKC2109) and 2500-50000 cells per well (PKCm). The cells were seeded onto the plate $4 \mathrm{~h}$ before the MTT treatment started, so that they had attached before treatment started. $10 \mu \mathrm{l}$ of MTT $(0.5 \mathrm{mg} / \mathrm{ml})$ of the MTT-Cell Proliferation Kit I (Roche Diagnostics, Basel, Switzerland) were added to each well containing $100 \mu \mathrm{l}$ culture medium and plates were incubated in the incubator for $4 \mathrm{~h}$. After this, $100 \mu \mathrm{l}$ of the solubilisation solution was added to each well and incubated in the incubator overnight to make the conversion of MTT visible. The formation of formazan crystals was measured by spectrophotometrical absorbance of the sample using
Sunrise $^{\mathrm{TM}}$ microplate reader (Tecan Austria GmbH, Salzburg, Austria) at a wavelength of $562 \mathrm{~nm}$. Analysis of data was processed with the Magellan Software.

\section{Cell transfection}

For chemical transfections, $3.2 \times 10^{4}$ of PKC2109 were seeded in $500 \mu \mathrm{l}$ per well onto a 24 -well plate the day before transfection. The cells were transfected with the GFP expressing plasmid pmaxGFP ${ }^{\mathrm{TM}}$ (Lonza, Cologne, Germany) to determine the transfection efficiency. The medium was changed on the day after transfection. For evaluation of the transfection process different parameters were assessed $24 \mathrm{~h}$ after transfection (see legend of Tables 2, 3, 4, 5): the morphology and cell quality (rating: 1 to 5), the amount of cells in suspension, probably being dead cells (rating: 0 to 2) and the fluorescence intensity (score system: lowest $[-]$ to highest $[+++]$ ).

\section{Nanofection}

The Nanofectin Kit (PAA) was used according to manufacturer's instructions. 0.5 or $1.0 \mu \mathrm{g}$ DNA was added each to $1.2,2,3.2$ or $4 \mu \mathrm{l}$ Nanofection solution whereas $1.5 \mu \mathrm{g}$ DNA was added to 2 or $3.2 \mu \mathrm{l}$ Nanofectin solution.

\section{Lipofection}

The Lipofectamin LTX + Plus Reagents Kit (Invitrogen) was used according to manufacturer's instructions. 0.25, 0.5 or $0.75 \mu \mathrm{g}$ of DNA was diluted in DMEM (5, 10 or $15 \mathrm{ng} / \mu \mathrm{l}$ DNA) and mixed thoroughly. The optimized volume of the Plus reagent $(0.25,0.5,0.75$ or $1 \mu \mathrm{l})$ was added to the diluted DNA. Lipofectamin LTX was added in different ratios $(1: 1-1: 4)$ to the diluted DNA/Plus solution.

For physical transfection, cells were splitted 1 day before the experiment. Prior transfection cells were washed twice with PBS, trypsinized and counted. Then, 0.5 and $1 \times 10^{6}$ cells were centrifuged ( $5 \mathrm{~min}, 180 \times \mathrm{g}$ ), resuspended in the respective solution and transfected either with pmaxGFP $^{\mathrm{TM}}$ or endotoxin-free purified pmaxGFP ${ }^{\mathrm{TM}}$. After transfection, cells were seeded onto $35 \mathrm{~mm}$ or $60 \mathrm{~mm}$ petri dishes (depending on cell number) containing pre-warmed 15\% FCS culture medium.

\section{Electroporation}

For electroporation, cell pellets of PKC2109 were washed twice with PBS and resuspended in $600 \mu \mathrm{l}$ of either Gene Pulser ${ }^{\mathrm{TM}}$ electroporation buffer (Bio-Rad, Munich, Germany), PBS or DMEM. DNA (1, 5, 10 or $20 \mu \mathrm{g}$ ) was added to the cell suspension and transferred into a $4 \mathrm{~mm}$ gap electroporation cuvette (Bio-Rad). Cells were electroporated with Gene Pulser II (Bio-Rad) using various settings (Voltage: 100 V, 230 V; High Capacity $500 \mu \mathrm{F}$ ). 


\section{Nucleofection}

For nucleofection of the cell lines PKCm, PKC2109, PEF0110 and PFF26 the Nucleofector ${ }^{\mathrm{TM}}$ II device (Lonza, Cologne, Germany) and the Amaxa ${ }^{\mathrm{TM}}$ Basic Nucleofector $^{\mathrm{TM}}$ Kit Primary Fibroblasts (Lonza) were used. 0.5 or $1 \times 10^{6}$ cells were mixed with $1,2,5,10$ or $20 \mu$ g of plasmid DNA and $100 \mu \mathrm{l}$ Nucleofector solution and nucleofected according to manufacturer's instructions with the recommended Nucleofector programs A24, T16, U12, U23 and V13.

If not stated otherwise, transfection efficiency was determined $24 \mathrm{~h}$ after transfection as the [(No. of GFP positive cells) / (No. of DAPI positive cells)] $\times 100$. Therefore, $24 \mathrm{~h}$ after transfection, cells were washed twice with PBS and fixated with $4 \%(\mathrm{~m} / \mathrm{v})$ paraformaldehyde (Merck, Darmstadt, Germany) for $20 \mathrm{~min}$ at RT in the dark. After fixation, cells were washed with PBS and incubated with DAPI-Methanol $(1 \mu \mathrm{g} / \mathrm{ml})$ for $10 \mathrm{~min}$ at $37^{\circ} \mathrm{C}$. Subsequently, cells were washed with methanol and PBS. Finally, the fixed cells were covered with PBS and analyzed using an inverted epifluorescence microscope (Axiovert 200M; Zeiss, Germany) equipped with an appropriate filter set.

\section{Additive gene transfer}

Various cell lines of PKC, PFF and PEF were genetically modified by nucleofection using the Amaxa $^{\text {TM }}$ Basic Nucleofector ${ }^{\mathrm{TM}}$ Kit Primary Fibroblasts and the Nucleofector II $^{\circledR}$ device (Lonza). $0.5 \times 10^{6}$ to $1 \times 10^{6}$ cells were transfected with 1-3 $\mu \mathrm{g}$ endotoxin-free purified and linearized conventional plasmids of 1.6 to $11.1 \mathrm{~kb}$ length and BAC vectors of $>150 \mathrm{~kb}$ length. After transfection, cells were plated either onto $35 \mathrm{~mm}$ or $60 \mathrm{~mm}$ petri dish depending on cell number using 15\% FCS in DMEM culture medium. After 24-48 h, selection was started with the following antibiotic concentrations: PKC $-10 \mu \mathrm{g} / \mu \mathrm{l}$

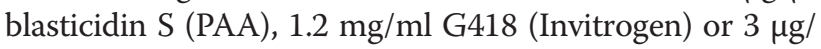
ml puromycin (PAA); PEF $-4 \mu \mathrm{g} / \mu \mathrm{l}$ blasticidin S; PFF 0.4 or $0.6 \mathrm{mg} / \mathrm{ml} \mathrm{G} 418$. Selection was conducted for $7-10$ days, including regular change of medium and 1 passaging step [10].

\section{Gene targeting}

Endotoxin-free purified BAC vectors of $>150 \mathrm{~kb}$ size were linearized and nucleofected into $0.5 \times 10^{6}$ or $1 \times 10^{6}$ PKC. 24-72 h after nucleofection the cells were counted and seeded onto 96-well plates for selection with $1.2 \mathrm{mg} / \mathrm{ml} \mathrm{G418} \mathrm{or} 6 \mu \mathrm{g} / \mathrm{ml}$ blasticidin S in 15\% DMEM culture medium for 7 days. Then, 96-well plates were screened for single cell colonies, which were splitted for DNA isolation and SCNT [10].

\section{Somatic cell nuclear transfer and embryo transfer}

In general, $48 \mathrm{~h}$ prior to SCNT cells were cultured in starvation medium containing all components of the normal culture medium, but only $0.5 \%$ FCS. Nuclear transfer was performed as described by Kurome et al. [40] and Klymiuk et al. [10]. The generated embryos were transferred into estrus synchronized gilts (ET), as published before [41], on the same day of nuclear transfer or 1-2 days later. Gilts were checked regularly after ET by ultrasonic examination for conception and monitoring of pregnancy.

For determination of the competence of cloned embryos in vitro PKCm, PFF26 and PEF0110 were used as donor cells at passage 4 and transferred to enucleated oocytes. After electric fusion and activation of the resulting embryos, they were cultured in porcine zygote medium (PZM5) [42] for 7 days. Then, the quality of the embryos was evaluated, they were fixed with acetic acid and methanol (1:3), nuclei of embryos were stained with $1 \%$ orcein (Sigma) and counted thereafter.

\section{Statistical analysis}

$X^{2}$-test was used to compare the rate of embryo development. The mean cell number of the embryos was compared using Student's $t$-test.

\section{Additional file}

Additional file 1: Single cell clone colonies of PKC2109 at P3. Single cell colonies were generated and analyzed after $\mathbf{5 - 8}$ days. The cells and formed colonies differed morphologically: fibroblast-like cells $[A, B, C$, $D, F]$, epithelial- and endothelial-like cells $[E]$, cell size (smaller $[A]$ ), colony compactness (cells very close $[A, C, E, F]$, gaps between cells $[B, D]$ ) and colony shape (clearly defined $[A, C]$, frayed colonies $[B, D, F]$ ). Scale bar $=100 \mu \mathrm{m}$.

\section{Competing interests}

The authors declare that they have no competing interests.

\section{Authors' contributions}

AR and AW conceived and carried out morphology, growth potential, transfection, additive gene transfer and gene targeting experiments and drafted the manuscript. MK, BK, VZ and HN were involved in nuclear transfer experiments. MK did the in vitro studies after SCNT and participated in embryo transfer. BK carried out embryo transfer and was responsible for animal care. NK conceived, coordinated and carried out molecular generation of constructs (plasmids and BACs) for additive gene transfer and gene targeting experiments and drafted the manuscript. EW coordinated and conceived pig projects, analyzed the data and drafted the manuscript. All authors read and approved the final manuscript.

\section{Acknowledgements}

The excellent technical support by Eva-Maria Jemiller and Tuna Güngör and the critical reading by Tobias Roland Richter are gratefully acknowledged. This work was financially supported by the German Research Council (FOR 535 'Xenotransplantation', FOR 793 'Mechanisms of Fracture Healing in Osteoporosis', Transregio-CRC 127 'Biology of xenogeneic cell, tissue and organ transplantation - from bench to bedside'), by the Federal Ministry for Education and Research (Leading-Edge Cluster 'm4 - Personalised Medicine and Targeted Therapies'), the Bavarian Research Council (FORZebRA, Az. 
802-08), the Mildred Scheel Stiftung für Krebsforschung, and by the Mukoviszidose Institut gemeinnützige Gesellschaft für Forschung und Therapie-entwicklung $\mathrm{mbH}$. The funders had no role in study design, data collection and analysis, decision to publish, or preparation of the manuscript.

\section{Author details}

${ }^{1}$ Chair for Molecular Animal Breeding and Biotechnology, and Laboratory for Functional Genome Analysis (LAFUGA), Gene Center, Ludwig-MaximiliansUniversität München, Feodor-Lynen-Straße 25, Munich 81377, Germany. ${ }^{2}$ Meiji University International Institute for Bio-Resource Research, Kawasaki, Japan.

Received: 30 May 2012 Accepted: 4 November 2012 Published: 9 November 2012

\section{References}

1. Aigner B, Renner S, Kessler B, Klymiuk N, Kurome M, Wunsch A, Wolf E: Transgenic pigs as models for translational biomedical research. $J \mathrm{Mol}$ Med 2010, 88:653-664

2. Lunney JK: Advances in swine biomedical model genomics. Int J Biol Sci 2007, 3:179-184

3. Klymiuk N, Aigner B, Brem G, Wolf E: Genetic modification of pigs as organ donors for xenotransplantation. Mol Reprod Dev 2010, 77:209-221.

4. Wolf E, Schernthaner W, Zakhartchenko V, Prelle K, Stojkovic M, Brem G: Transgenic technology in farm animals-progress and perspectives. Exp Physiol 2000, 85:615-625.

5. Robl JM, Wang Z, Kasinathan P, Kuroiwa Y: Transgenic animal production and animal biotechnology. Theriogenology 2007, 67:127-133.

6. Hauschild J, Petersen B, Santiago Y, Queisser AL, Carnwath JW, Lucas-Hahn A, Zhang L, Meng X, Gregory PD, Schwinzer R, et al: Efficient generation of a biallelic knockout in pigs using zinc-finger nucleases. Proc Natl Acad Sci US A 2011, 108:12013-12017.

7. Rogers CS, Hao Y, Rokhlina T, Samuel M, Stoltz DA, Li Y, Petroff E, Vermeer DW, Kabel AC, Yan Z, et al: Production of CFTR-null and CFTR-DeltaF508 heterozygous pigs by adeno-associated virus-mediated gene targeting and somatic cell nuclear transfer. J Clin Invest 2008, 118:1571-1577.

8. Klymiuk N, Mundhenk L, Kraehe K, Wuensch A, Plog S, Emrich D, Langenmayer MC, Stehr M, Holzinger A, Kroner C, et al: Sequential targeting of CFTR by BAC vectors generates a novel pig model of cystic fibrosis. J Mol Med (Berl) 2012, 90:597-608.

9. Klymiuk N, van Buerck L, Bahr A, Offers M, Kessler B, Wuensch A, Kurome M, Thormann M, Lochner K, Nagashima H, et al: Xenografted islet cell clusters from INSLEA29Y transgenic pigs rescue diabetes and prevent immune rejection in humanized mice. Diabetes 2012, 61:1527-1532.

10. Klymiuk N, Bocker W, Schonitzer V, Bahr A, Radic T, Frohlich T, Wunsch A,

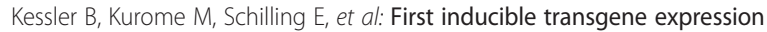
in porcine large animal models. FASEB J 2012, 26:1086-1099.

11. Campbell KH, Alberio R, Choi I, Fisher P, Kelly RD, Lee JH, Maalouf W: Cloning: eight years after dolly. Reprod Domest Anim 2005, 40:256-268.

12. Kumar BM, Jin HF, Kim JG, Ock SA, Hong Y, Balasubramanian S, Choe SY, Rho GJ: Differential gene expression patterns in porcine nuclear transfer embryos reconstructed with fetal fibroblasts and mesenchymal stem cells. Dev Dyn 2007, 236:435-446.

13. Jin HF, Kumar BM, Kim JG, Song HJ, Jeong YJ, Cho SK, Balasubramanian S, Choe SY, Rho GJ: Enhanced development of porcine embryos cloned from bone marrow mesenchymal stem cells. Int J Dev Biol 2007, 51:85-90.

14. Polejaeva IA, Chen SH, Vaught TD, Page RL, Mullins J, Ball S, Dai Y, Boone J, Walker $\mathrm{S}$, Ayares DL, et al: Cloned pigs produced by nuclear transfer from adult somatic cells. Nature $2000,407: 86-90$

15. Petersen B, Lucas-Hahn A, Oropeza M, Hornen N, Lemme E, Hassel P, Queisser AL, Niemann H: Development and validation of a highly efficient protocol of porcine somatic cloning using preovulatory embryo transfer in peripubertal gilts. Cloning Stem Cells 2008, 10:355-362

16. Onishi A, Iwamoto M, Akita T, Mikawa S, Takeda K, Awata T, Hanada H, Perry AC: Pig cloning by microinjection of fetal fibroblast nuclei. Science 2000, 289:1188-1190.

17. Kurome M, Ueda H, Tomii R, Naruse K, Nagashima H: Production of transgenic-clone pigs by the combination of ICSI-mediated gene transfer with somatic cell nuclear transfer. Transgenic Res 2006,

15:229-240
18. Yin XJ, Tani T, Yonemura I, Kawakami M, Miyamoto K, Hasegawa R, Kato Y, Tsunoda Y: Production of cloned pigs from adult somatic cells by chemically assisted removal of maternal chromosomes. Biol Reprod 2002 67:442-446.

19. Chen CA, Okayama H: Calcium phosphate-mediated gene transfer: a highly efficient transfection system for stably transforming cells with plasmid DNA. Biotechniques 1988, 6:632-638.

20. Felgner PL, Gadek TR, Holm M, Roman R, Chan HW, Wenz M, Northrop JP, Ringold GM, Danielsen M: Lipofection: a highly efficient, lipid-mediated DNA-transfection procedure. Proc Natl Acad Sci U S A 1987, 84:7413-7417.

21. Orth P, Weimer A, Kaul G, Kohn D, Cucchiarini M, Madry H: Analysis of novel nonviral gene transfer systems for gene delivery to cells of the musculoskeletal system. Mol Biotechnol 2008, 38:137-144.

22. Neumann E, Schaefer-Ridder M, Wang Y, Hofschneider PH: Gene transfer into mouse lyoma cells by electroporation in high electric fields. EMBO J 1982, 1:841-845

23. Schakowski F, Buttgereit $P$, Mazur M, Marten A, Schottker B, Gorschluter M, Schmidt-Wolf IG: Novel non-viral method for transfection of primary leukemia cells and cell lines. Genet Vaccines Ther 2004, 2:1.

24. Liu CP, Slate DL, Gravel R, Ruddle FH: Biological detection of specific mRNA molecules by microinjection. Proc Natl Acad Sci U S A 1979, 76:4503-4506.

25. Eglitis MA, Anderson WF: Retroviral vectors for introduction of genes into mammalian cells. Biotechniques 1988, 6:608-614.

26. Grupp C, Muller GA: Renal fibroblast culture. Exp Nephrol 1999, 7:377-385.

27. Kaissling B, Hegyi I, Loffing J, Le Hir M: Morphology of interstitial cells in the healthy kidney. Anat Embryol (Berl) 1996, 193:303-318.

28. Yashiki S, Umegaki R, Kino-Oka M, Taya M: Evaluation of attachment and growth of anchorage-dependent cells on culture surfaces with type I collagen coating. J Biosci Bioeng 2001, 92:385-388.

29. Leclere PG, Panjwani A, Docherty R, Berry M, Pizzey J, Tonge DA: Effective gene delivery to adult neurons by a modified form of electroporation. J Neurosci Methods 2005, 142:137-143.

30. Maurisse R, De Semir D, Emamekhoo H, Bedayat B, Abdolmohammadi A, Parsi $H$, Gruenert DC: Comparative transfection of DNA into primary and transformed mammalian cells from different lineages. BMC Biotechnol 2010, 10:9.

31. Hagemann C, Meyer C, Stojic J, Eicker S, Gerngras S, Kuhnel S, Roosen K, Vince $\mathrm{GH}$ : High efficiency transfection of glioma cell lines and primary cells for overexpression and RNAi experiments. J Neurosci Methods 2006, 156:194-202.

32. Lakshmipathy U, Pelacho B, Sudo K, Linehan $U$, Coucouvanis E, Kaufman DS, Verfaillie CM: Efficient transfection of embryonic and adult stem cells. Stem Cells 2004, 22:531-543.

33. Nakayama A, Sato M, Shinohara M, Matsubara S, Yokomine T, Akasaka E, Yoshida M, Takao S: Efficient transfection of primarily cultured porcine embryonic fibroblasts using the amaxa nucleofection system. Cloning Stem Cells 2007, 9:523-534.

34. Faast R, Harrison SJ, Beebe LF, Mcllfatrick SM, Ashman RJ, Nottle MB: Use of adult mesenchymal stem cells isolated from bone marrow and blood for somatic cell nuclear transfer in pigs. Cloning Stem Cells 2006, 8:166-173.

35. Kuhholzer B, Hawley RJ, Lai L, Kolber-Simonds D, Prather RS: Clonal lines of transgenic fibroblast cells derived from the same fetus result in different development when used for nuclear transfer in pigs. Biol Reprod 2001, 64:1695-1698.

36. Powell AM, Talbot NC, Wells KD, Kerr DE, Pursel VG, Wall RJ: Cell donor influences success of producing cattle by somatic cell nuclear transfer. Biol Reprod 2004, 71:210-216.

37. Kemter E, Lieke T, Kessler B, Kurome M, Wuensch A, Summerfield A, Ayares D, Nagashima H, Baars W, Schwinzer R, Wolf E: Human TNF-related apoptosis-inducing ligand-expressing dendritic cells from transgenic pigs attenuate human xenogeneic $T$ cell responses. Xenotransplantation 2012, 19:40-51.

38. Matsumoto S, Okumura K, Ogata A, Hisatomi Y, Sato A, Hattori K, Matsumoto M, Kaji Y, Takahashi M, Yamamoto T, et al: Isolation of tissue progenitor cells from duct-ligated salivary glands of swine. Cloning Stem Cells 2007, 9:176-190.

39. Henegariu O, Heerema NA, Lowe Wright L, Bray-Ward P, Ward DC, Vance $\mathrm{GH}$ : Improvements in cytogenetic slide preparation: controlled chromosome spreading, chemical aging and gradual denaturing. Cytometry 2001, 43:101-109. 
40. Aigner B, Klymiuk N, Wolf E: Transgenic pigs for xenotransplantation: selection of promoter sequences for reliable transgene expression. Curr Opin Organ Transplant 2010, 15:201-206.

41. Besenfelder U, Modl J, Muller M, Brem G: Endoscopic embryo collection and embryo transfer into the oviduct and the uterus of pigs. Theriogenology 1997, 47:1051-1060.

42. Yoshioka K: Development and application of a chemically defined medium for the in vitro production of porcine embryos. J Reprod Dev 2011, 57:9-16.

doi:10.1186/1472-6750-12-84

Cite this article as: Richter et al.: Potential of primary kidney cells for somatic cell nuclear transfer mediated transgenesis in pig. BMC Biotechnology 2012 12:84.

\section{Submit your next manuscript to BioMed Central and take full advantage of:}

- Convenient online submission

- Thorough peer review

- No space constraints or color figure charges

- Immediate publication on acceptance

- Inclusion in PubMed, CAS, Scopus and Google Scholar

- Research which is freely available for redistribution 